\title{
Biosynthesis of Biocompatible Cadmium Telluride Quantum Dots Using Yeast Cells
}

\author{
Haifeng Bao, Na Hao, Yunxia Yang, and Dongyuan Zhao ( $\square)$ \\ Department of Chemical Engineering, Monash University, Clayton, VIC3800, Australia \\ Received: 14 April 2010 / Revised: 9 May 2010 / Accepted: 11 May 2010 \\ (C) The Author(s) 2010. This article is published with open access at Springerlink.com
}

\begin{abstract}
We demonstrate a simple and efficient biosynthesis method to prepare easily harvested biocompatible cadmium telluride (CdTe) quantum dots (QDs) with tunable fluorescence emission using yeast cells. Ultraviolet-visible (UV-vis) spectroscopy, photoluminescence (PL) spectroscopy, X-ray diffraction (XRD), and transmission electron microscopy (TEM) confirm that the CdTe QDs are formed via an extracellular growth and subsequent endocytosis pathway and have size-tunable optical properties with fluorescence emission from 490 to $560 \mathrm{~nm}$ and a cubic zinc blende structure with good crystallinity. In particular, the CdTe QDs with uniform size (2-3.6 $\mathrm{nm}$ ) are protein-capped, which makes them highly soluble in water, and in situ bio-imaging in yeast cells indicates that the biosynthesized QDs have good biocompatibility. This work provides an economic and environmentally friendly approach to synthesize highly fluorescent biocompatible CdTe QDs for bio-imaging and bio-labeling applications.
\end{abstract}

\section{KEYWORDS}

Cadmium telluride (CdTe) quantum dots, biosynthesis, biocompatible, in situ bio-imaging

\section{Introduction}

Semiconductor nanocrystal quantum dots (QDs) exhibit unique size-dependent electronic and optical properties due to the quantum confinement effect [1,2]. To date, many kinds of QDs with different size, shape, and composition [3-5] have been extensively investigated for not only their theoretical fundamentals but also their practical applications, including in solar cells [6], optoelectronic transistor components [7], and fluorescent biological labels [8, 9]. Among various QDs, cadmium telluride (CdTe) QDs have been widely used in industrial and biomedical applications [7, 10-12] because of their tunable photoluminescence within the visible range when excited by a single excitation wavelength. For instance, CdTe QDs are believed to be promising probes in the bio-imaging of living cells [13] because of their many advantages such as higher photostability, more controllable and narrower emission bands, and higher quantum yield in comparison with conventional fluorescent dyes. To date, two successful routes for the synthesis of highly fluorescent CdTe QDs have been developed, namely the organometallic method $[3,14,15]$ and water-based synthesis [16-19] with thiols as capping ligands. However, these reactions need to be performed at high temperature. Moreover, the resulting QDs need to be attached with proteins or capped with layers of 
low toxicity in order to decrease their toxicity in bio-imaging and bio-labeling applications $[5,10]$. The development of a cheap, effective, and reproducible method to prepare CdTe QDs with controlled structures and properties on a large scale remains a great challenge.

More recently, the biosynthesis of QDs has been developed and attracted significant attention. This involves the use of biological organisms to prepare QDs with controlled size, shape, chemical composition, and functionality [20]. For example, several microorganisms including Fusarium oxysporum [21] and Schizosaccharomyces pombe [22] have been employed to synthesize CdS QDs, whilst Torulopsis species [23] have been used to prepare PbS QDs, and sulfate reducing bacteria and Rhodobacter sphaeroides to synthesize ZnS QDs [24]. Sweeney et al. reported that CdS QDs can be formed intracellularly in E. coli cells incubated with cadmium chloride and sodium sulfide [25]. All these environmentally friendly approaches are achieved at ambient temperatures. However, complicated procedures are required to isolate the intracellularly grown QDs and the photoluminescence of these biosynthesized QDs has been seldom reported [26-28]. Therefore, it is of great importance to develop a simple and cheap biosynthesis approach which can prepare highly fluorescent QDs with uniform size and extend their biological applications, especially for CdTe QDs-one of the most popular nanocrystals.

In this paper, we demonstrate a simple and efficient biosynthesis of highly fluorescent CdTe QDs with uniform size $(2.0-3.6 \mathrm{~nm})$ by incubating a type of widely used and easily cultured microorganism-yeast cells (Saccharomyces cerevisiae) - with cheap inorganic $\mathrm{Cd}$ and Te salt precursors, which has a high yield of nearly 90\%. The extracellularly bio-grown CdTe QDs can be easily harvested and display tunable sizedependent emission from 490 to $560 \mathrm{~nm}$ with a relatively high photoluminescence (PL) quantum yield of $\sim 33 \%$ due to their high crystallinity. Furthermore, the CdTe QDs are naturally capped with proteins in the biosystem, and show excellent water solubility, great stability, and biocompatibility. Our work can not only provide an economic and environmentally friendly route to prepare highly fluorescent biocompatible CdTe
QDs on a gram scale, but also extend bio-imaging and bio-labeling applications of biosynthesized QDs.

\section{Experimental}

\subsection{Materials}

Cadmium chloride hemipentahydrate $\left(\mathrm{CdCl}_{2} \cdot 2 \cdot 5 \mathrm{H}_{2} \mathrm{O}\right)$, sodium citrate tribasic dihydrate $\left(\mathrm{C}_{6} \mathrm{H}_{5} \mathrm{O}_{7} \mathrm{Na}_{3} \cdot 2 \mathrm{H}_{2} \mathrm{O}\right)$, sodium tellurite $\left(\mathrm{Na}_{2} \mathrm{TeO}_{3}\right)$ (100 mesh, $\left.99 \%\right)$, mercaptosuccinic acid (MSA), sodium borohydride $\left(\mathrm{NaBH}_{4}\right.$, $99.995 \%)$, sodium nitrate $\left(\mathrm{NaNO}_{3}\right)$, dipotassium hydrogenphosphate $\left(\mathrm{K}_{2} \mathrm{HPO}_{4}\right)$, potassium chloride $(\mathrm{KCl})$, magnesium sulfate hepta-hydrate $\left(\mathrm{MgSO}_{4} \cdot 7 \mathrm{H}_{2} \mathrm{O}\right)$, Rhodamine 6G, and ethanol (anhydrous, $\geqslant 99.95 \%$ ) were purchased from Sigma-Aldrich Corporation. All these chemicals were used without further purification. The water was deionized through a Nex Power 1000 water purification system (Human Corporation).

\subsection{Synthesis}

The yeast cells were grown with aeration at $35^{\circ} \mathrm{C}$ in a modified Czapek's medium. In a typical procedure, $450 \mathrm{~g}$ of sucrose, $15 \mathrm{~g}$ of $\mathrm{NaNO}_{3}, 5.0 \mathrm{~g}$ of $\mathrm{K}_{2} \mathrm{HPO}_{4}$, $2.5 \mathrm{~g}$ of $\mathrm{KCl}, 2.5 \mathrm{~g}$ of $\mathrm{MgSO}_{4} \cdot 7 \mathrm{H}_{2} \mathrm{O}$, and $30.0 \mathrm{~g}$ of sodium citrate tribasic dihydrate were dissolved in $5 \mathrm{~L}$ of deionized water under stirring and placed in a $5000 \mathrm{~mL}$ conical flask and incubated with yeast cells for 2 days at $35^{\circ} \mathrm{C}$. When the absorbance of the cell culture reached 0.6 at $600 \mathrm{~nm}\left(A_{600}\right)$, the resulting yeast solution was added with $400 \mathrm{~mL}$ of cadmium chloride $\left(\mathrm{CdCl}_{2}\right)(0.04 \mathrm{~mol} / \mathrm{L}), 100 \mathrm{~mL}$ of $\mathrm{Na}_{2} \mathrm{TeO}_{3}(0.04 \mathrm{~mol} / \mathrm{L})$, $7.5 \mathrm{~g}$ of MSA, and $5.0 \mathrm{~g}$ of $\mathrm{NaBH}_{4}$, followed by incubation at $35{ }^{\circ} \mathrm{C}$ in a water bath with continuous stirring ( $500 \mathrm{r} / \mathrm{min}$ ). The biosynthesized CdTe QDs were centrifuged at $5000 \mathrm{r} / \mathrm{min}$ for $15 \mathrm{~min}$ to remove the yeast cells, and dialyzed three times at room temperature $\left(25^{\circ} \mathrm{C}\right)$ by using a dialysis membrane (MWCO-14 000, USA) to remove the residual chemicals. Finally, $1.15 \mathrm{~g}$ of as-biosyn-thesized CdTe QD products was obtained with a yield of nearly $90 \%$, calculated from the amount of $\mathrm{Na}_{2} \mathrm{TeO}_{3}$. The capped proteins were obtained by treating the as-biosynthesized CdTe QDs with $\mathrm{HCl}$ to dissolve the CdTe for the high-performance liquid chromatography (HPLC) measurements. 


\subsection{Characterization}

X-ray powder diffraction (XRD) patterns were recorded using a Bruker D8 X-ray diffractometer (Germany) with Ni-filtered $\mathrm{Cu} \mathrm{K} \alpha$ radiation $(40 \mathrm{kV}, 40 \mathrm{~mA})$. Transmission electron microscopy (TEM) and highresolution TEM (HRTEM) images were taken with a JEM-2100F (UHR) (JEOL, Japan) electron microscope operating at $200 \mathrm{kV}$. TEM samples were prepared by dropping suspensions on copper grids and dried at room temperature $\left(25^{\circ} \mathrm{C}\right)$ for $24 \mathrm{~h}$. After incubation for different durations, the crude solution was centrifuged at $5000 \mathrm{r} / \mathrm{min}$ for $10 \mathrm{~min}$ to precipitate the yeast. The supernatant was collected for the measurement of the ultraviolet-visible (UV-vis) and PL spectra. The optical characterizations were performed at room temperature $\left(25^{\circ} \mathrm{C}\right)$. UV-vis absorption spectra were recorded on a Cary 500 UV/Vis/near-infrared (IR) Varian spectrophotometer (USA). PL spectra were obtained with a PerkinElmer LS 55 luminescence spectrometer (USA) with an excitation wavelength of $400 \mathrm{~nm}$. The PL quantum yields of the biosynthesized CdTe QDs were calculated by comparison with a solution of Rhodamine 6G in anhydrous ethanol according to the procedure reported previously in Ref. [29]. Laser scanning confocal microscopy (LSCM) measurements were carried out on Olympus FV1000 instrument with an $\mathrm{Ar} / \mathrm{Kr}$ laser. The yeast cells were separated by centrifugation at $1000 \mathrm{r} / \mathrm{min}$ for the LSCM experiments. Fourier transform infrared (FT-IR) spectra were obtained with a PerkinElmer Spectrum 100 spectrometer (USA) using $\mathrm{KBr}$ pellets. High-performance liquid chromatography (HPLC) was performed at $25^{\circ} \mathrm{C}$ on a Waters 650E Advanced Protein Purification system (USA), with a Shim-Pack Diol-150 HPLC column (Shimadzu, Kyoto, Japan) equilibrated with $0.05 \mathrm{~mol} / \mathrm{L} \mathrm{Na}_{2} \mathrm{SO}_{4}$ at a flow rate of $1.0 \mathrm{~mL} / \mathrm{min}$ and a gradient control monitoring the separation at $280 \mathrm{~nm}$ and with a Waters 486 tunable wavelength detector. The following molecular mass markers were used: Bovine serum albumin (BSA, 66.2 kD), alpha-chymotrypsin $(25.0 \mathrm{kD})$, and lysozyme $(14.4 \mathrm{kD})$. The relationship between the retention time $\left(t_{\mathrm{R}}\right)$ and the molecular mass $(M)$ can be expressed by a simple equation $t_{R}=$ $b \lg (M)+c$, where $b$ and $c$ are constants. Fitting this equation gives the molecular mass of the proteins.

\section{Results and discussion}

The CdTe QDs were synthesized by an extracellular growth approach by incubating cheap inorganic salts $\mathrm{CdCl}_{2}$ and $\mathrm{NaTeO}_{3}$ with yeast cells in a modified Czapek's medium at mild temperatures $\left(25-35^{\circ} \mathrm{C}\right)$. UV-vis absorption and PL spectra of the biosynthesized CdTe QDs were used to monitor the growth of CdTe QDs during the incubation (Fig. 1). After incubation for 1 day at $35^{\circ} \mathrm{C}$, the CdTe QDs show an intense narrow absorption at $\sim 440 \mathrm{~nm}$ from the first electronic transition (Fig. 1(a)) and a strong emission centered at $492 \mathrm{~nm}$ with a narrow full width at half maximum (fwhm) (about $40 \mathrm{~nm}$ ) in the PL spectra (Fig. 1(b)), indicating that the QDs have a narrow size distribution. With the increase of the incubation time, the absorption edge and the PL maximum of the biosynthesized CdTe QDs both shift towards longer wavelengths, suggesting an increase of the particle size. The particle size may be calculated based on the quantum confinement using the formula reported in Ref. [30]: the values ranged from 2.0 to $3.6 \mathrm{~nm}$, based on the shift of the PL band from 490 to $560 \mathrm{~nm}$ (Fig. 1(b)). The fwhm increases with the incubation time and reaches $75 \mathrm{~nm}$ when emission wavelength is $556 \mathrm{~nm}$. This is consistent with an increase in the size of the CdTe QDs. The size increase can be attributed to the effect of Ostwald ripening [31]. The photograph of as-biosynthesized CdTe QDs incubated for 8 days at $35^{\circ} \mathrm{C}\left(\lambda_{\mathrm{em}}=556 \mathrm{~nm}\right.$, Fig. 1(b) inset) shows that the QDs have strong green emission under ambient room light. The PL quantum yield of this sample was determined to be about $33 \%$. CdTe QDs with tunable size-dependent emission from blue to green can be easily harvested by controlling the incubation time of the yeast cells.

The morphology and crystallinity of the biosynthesized CdTe QDs were analyzed by TEM and XRD. TEM images reveal that the biosynthesized CdTe QDs incubated for 8 days at $35^{\circ} \mathrm{C}$ are well dispersed particles with a uniform diameter of $\sim 3.6 \mathrm{~nm}$ (Fig. 2(a)). HRTEM image (Fig. 2(a) inset) illustrates that the QDs have lattice planes with spacing of $0.32 \mathrm{~nm}$, corresponding to the $d(200)$ spacing of the cubic zinc blende structure of bulk CdTe. It also confirms that the individual nanoparticle is a single crystal. When the incubation time is shortened to 2 days at $35^{\circ} \mathrm{C}$, the 


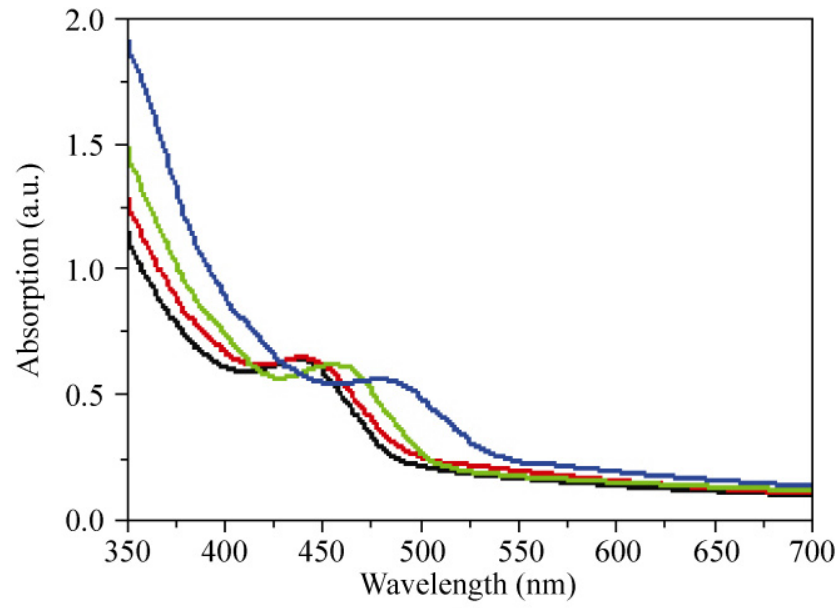

(a)

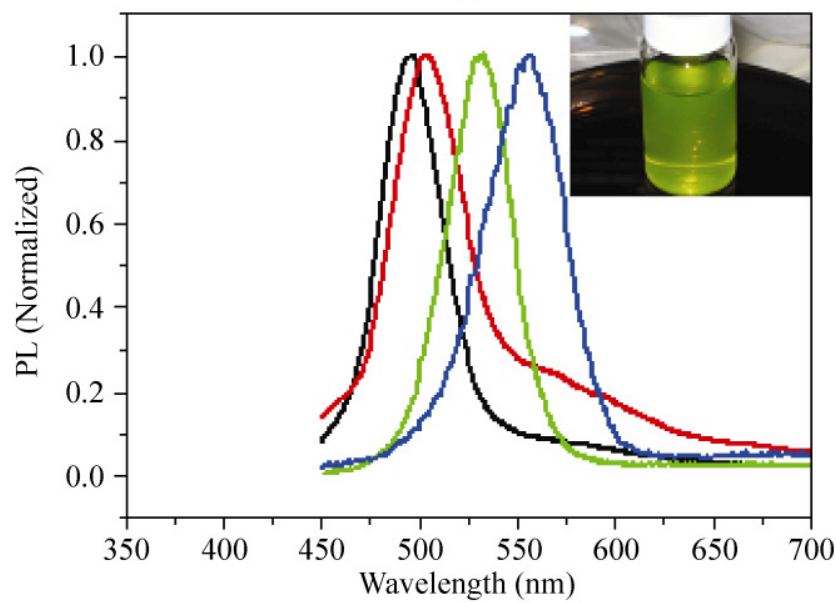

(b)

Figure 1 UV-vis (a) and PL (b) spectra of the biosynthesized CdTe QDs, which were taken from the reaction flask and centrifugation to remove the yeast cells after incubation at $35^{\circ} \mathrm{C}$ in the open air for 1 day (black line), 2 days (red line), 4 days (green line), and 8 days (blue line). The inset in (b) is a photograph of the as-biosynthesized CdTe QDs (incubated for 8 days at $35^{\circ} \mathrm{C}, \lambda_{\mathrm{em}}=$ $556 \mathrm{~nm}$ ) under ambient room light

resulting CdTe QDs sample are also well dispersed single-crystalline particles with a smaller diameter of $\sim 2.2 \mathrm{~nm}$ (Fig. S-1 in the Electronic Supplementary Material (ESM)). The XRD pattern of the biosynthesized CdTe QDs (Fig. 2(b)) shows a broad diffraction peak at $2 \theta \sim 26.7^{\circ}$, which can be indexed to the (200) reflection for cubic CdTe according to the standard pattern (JCPDS card 75-2083). The broad peak suggests the presence of small nanoparticles, which is consistent with the HRTEM image.

FT-IR spectroscopy was used to determine the chemical composition of the ligands capping on the

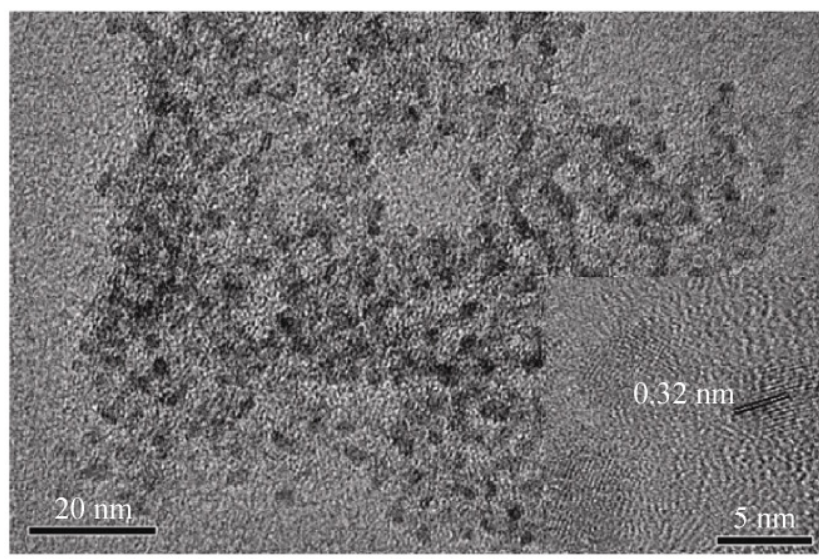

(a)

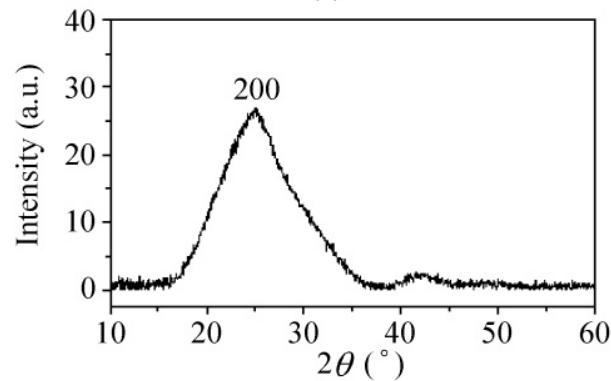

(b)

Figure 2 (a) TEM image with HRTEM image in the inset and (b) XRD pattern of the CdTe QDs extracellularly biogrown with the yeast cells at $35^{\circ} \mathrm{C}$ for 8 days

surface of the QDs. The biosynthesized CdTe QDs show two absorption bands centered at 1650 and $1566 \mathrm{~cm}^{-1}$, which can be attributed to the typical amide I and II absorptions of protein molecules, respectively (Fig. 3). This provides firm evidence that the CdTe QDs are capped with proteins. HPLC performed on a protein purification system was used to analyze the composition and the molecular mass of the capped proteins. The results of HPLC experiments show the presence of two proteins: one has a molecular mass of $7.7 \mathrm{kD}$ with a content of $\sim 93.4 \%$, and the other has a molecular mass of $692 \mathrm{kD}$ with a content of $\sim 6.6 \%$ (Fig. S-2 in the ESM). It should be noted that no protein was added to the culture medium, indicating that the protein caps are generated from yeast cells during the incubation process. Based on the above results, it is concluded that the yeast cells used in our biosynthesis can not only provide an environmentally friendly reaction system for the growth of uniform CdTe QDs, but also generate protein ligands to act as caps on the nanoparticles. These caps inhibit 


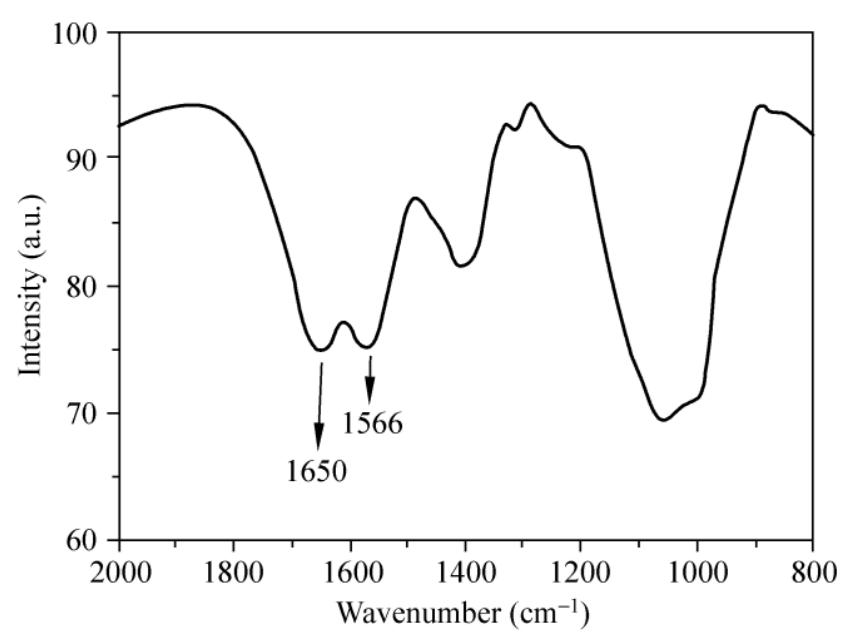

Figure 3 The FT-IR spectrum of the biosynthesized CdTe QDs incubated with yeast cells at $35^{\circ} \mathrm{C}$ for 8 days

aggregation of the QDs and ensure their highly fluorescent properties.

Although the yeast cells can grow in a temperature range from 5 to $35^{\circ} \mathrm{C}$, the QDs grow better at a relatively high temperature. UV-vis spectroscopy showed that when the reaction time was increased from 1 day to 8 days, the absorption edge of the CdTe samples showed a much larger red-shift $(70 \mathrm{~nm})$ at $35^{\circ} \mathrm{C}$ (Fig. 1) than that $(20 \mathrm{~nm})$ observed at $25^{\circ} \mathrm{C}$ (Fig. 4). This suggests that the growth of the CdTe QDs is much slower at $25^{\circ} \mathrm{C}$, and that the size can be easily tuned by choosing the appropriate reaction time at a relatively high temperature $\left(35^{\circ} \mathrm{C}\right)$.

Laser confocal scanning microscopy (LCSM) under excitation by a 488-nm laser with bright field imaging (Fig. 5) was used to examine the in situ bio-images of

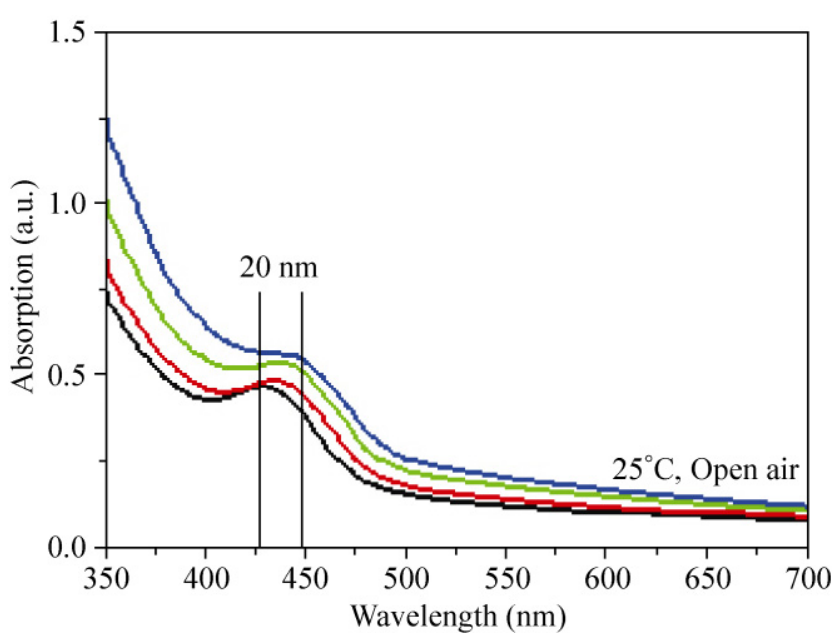

Figure 4 UV-vis spectra of the CdTe QDs biosynthesized by the extracellular growth approach after incubation with the yeast cells at $25^{\circ} \mathrm{C}$ in the open air for 1 day (black line), 2 days (red line), 4 days (green line), and 8 days (blue line)

the yeast cells incubated at $35^{\circ} \mathrm{C}$ for 8 days with the CdTe QDs. Interestingly, the confocal images of the yeast cells show obvious green emission from the biosynthesized CdTe QDs. The overlaid image indicates that the CdTe QDs are well dispersed only in the cytoplasm and nucleus of yeast cells, and no QD particles were found in the cell membrane (Fig. 5). In a control experiment without the $\mathrm{Cd}$ and Te precursors, only yeast cells were observed in the bright field image and no emission image was obtained under excitation by the $488-\mathrm{nm}$ laser (Fig. S-3 in the ESM). A series of optical slices were taken in steps of $1 \mu \mathrm{m}$ in the $z$-direction and eight images were collected as shown in Fig. 6. Each slice shows only a portion of the entire

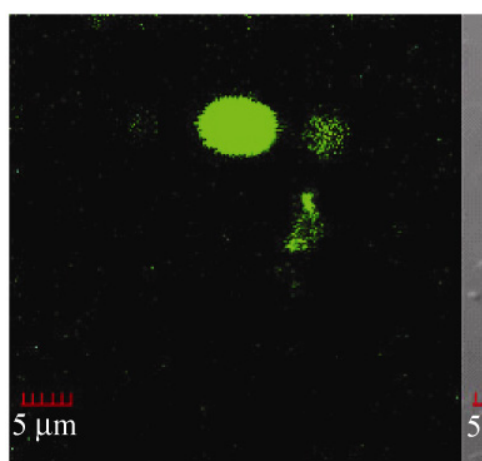

(a)

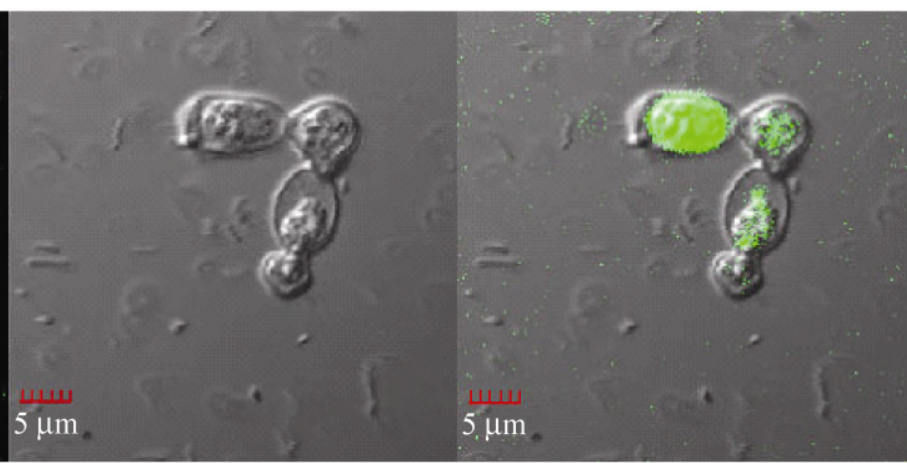

(b) (c)

Figure 5 Confocal images of the yeast cells incorporated with the CdTe QDs at $35{ }^{\circ} \mathrm{C}$ for 8 days, recorded under excitation by a 488-nm laser giving green-emission (a), the bright field image (b), and the overlaid image (c) 


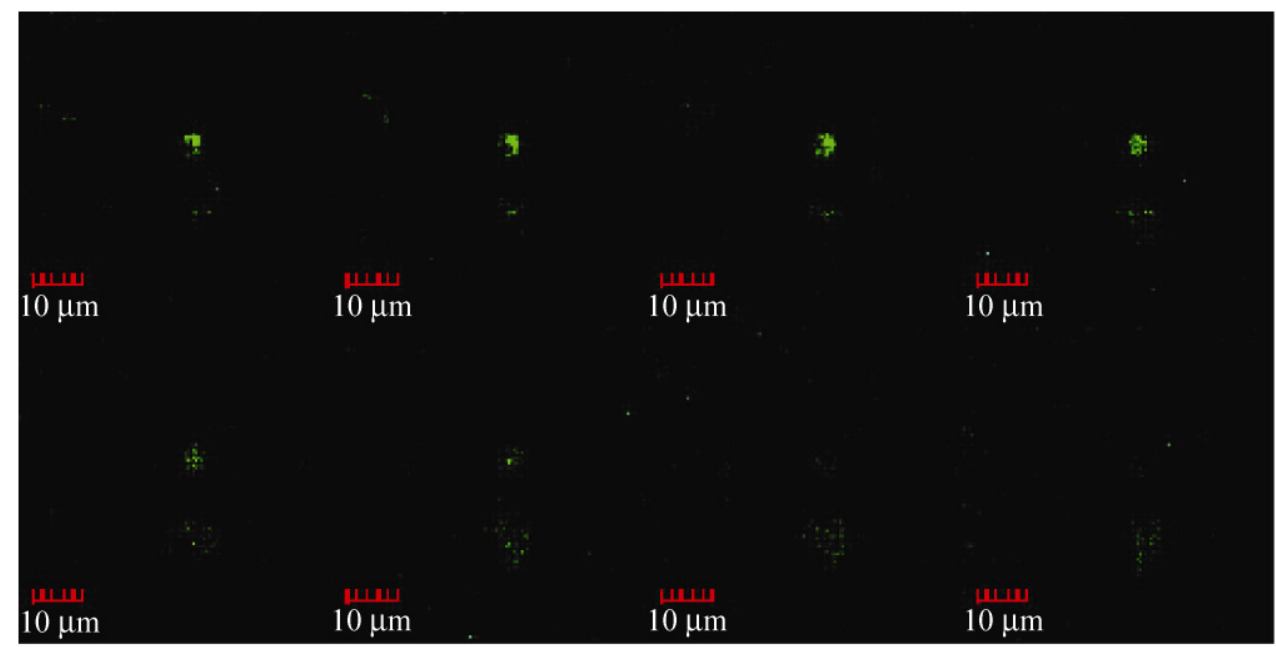

Figure 6 A series of optical slices taken from a yeast cell in steps of $1 \mu \mathrm{m}$ along the $z$-direction

sample, further confirming that the CdTe QDs are dispersed over almost all of the cytoplasm and nucleus parts of yeast cells. This result is quite different from the report of the intracellular biosynthesis of CdSe QDs [27], which were mainly dispersed in the membrane and cytoplasm of the cells.
Based on the above observations, we speculate that the formation of protein-capped CdTe QDs with uniform size in the yeast cells possibly involves extracellular growth, and a subsequent endocytosis pathway is responsible for the observed bio-images (Fig. 7). In view of the fact that only an amorphous Te

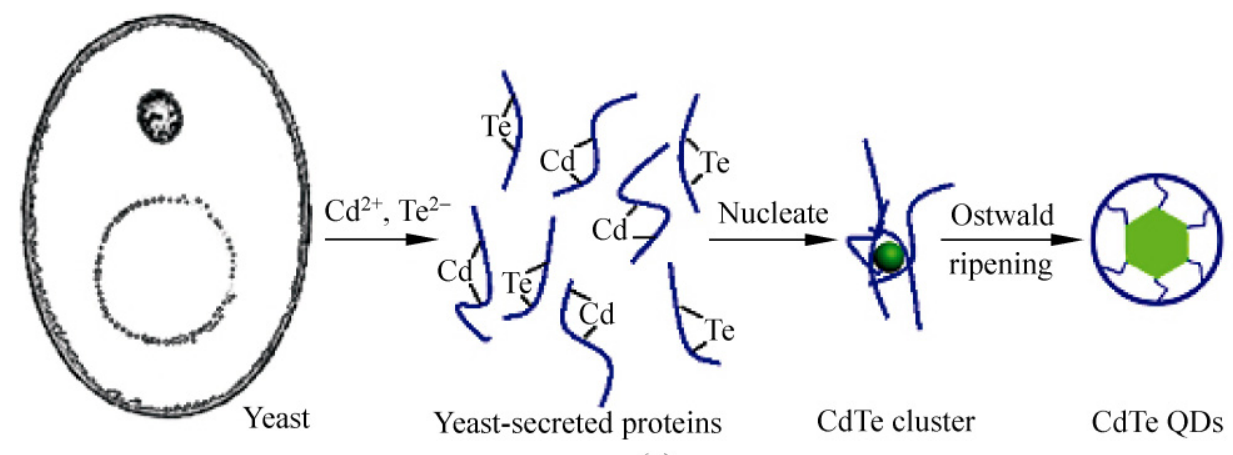

(a)

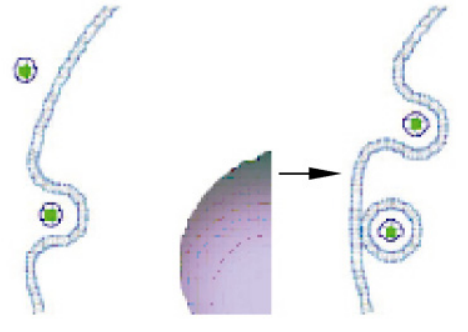

I

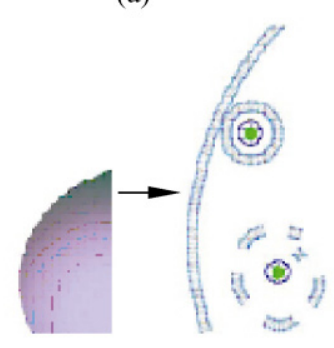

III

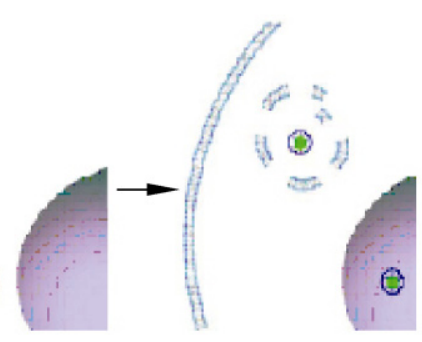

IV

(b)

Figure 7 Schematic representation of a possible extracellular growth pathway (a) for the biosynthesis of protein-capped CdTe QDs, and an endocytosis pathway (b) which explains the in situ bio-images. In the endocytosis pathway, step I involves the QDs adhering to the cell membrane via electrostatic interactions, in step II they become embedded by deforming the membrane and endocytose into the cell, in step III they are released from the endosome into the cytoplasm by disruption of the endosomal membrane, and in step IV enter the nucleus via a nuclear translocation 
colloid is obtained on simply mixing the $\mathrm{Cd}$ and $\mathrm{Te}$ precursors in the medium without yeast cells, it is believed that the yeast cells play a key role in the formation of the protein-capped CdTe QDs. When $\mathrm{Te}^{2-}$ ions formed according to the following equation:

$$
4 \mathrm{TeO}_{3}^{2-}+3 \mathrm{BH}_{4}^{-} \longrightarrow 4 \mathrm{Te}^{2-}+3 \mathrm{BO}_{2}^{-}+6 \mathrm{H}_{2} \mathrm{O}
$$

are mixed with $\mathrm{Cd}^{2+}$ ions and incubated with the yeast medium, the cells are forced to initiate a specific defense mechanism under the extreme environmental conditions, generating proteins to coordinate with $\mathrm{Cd}$ and $\mathrm{Te}$ ions in an effort to detoxify the metal ions $[32,33]$. In this biochemical process, yeast-secreted proteins coordinated with $\mathrm{Cd}^{2+}$ and $\mathrm{Te}^{2-}$ ions can eventually become incorporated as caps on the surface of the QDs forming a coating layer:

$$
\mathrm{CdL}_{1}+\mathrm{TeL}_{2} \longrightarrow \mathrm{CdTe}+\mathrm{L}_{1}+\mathrm{L}_{2}
$$

where $L_{1}$ and $L_{2}$ are yeast-secreted proteins.

These caps not only improve the biocompatibility but also ensure the highly fluorescent properties. The CdTe clusters (nuclei) subsequently grow in the medium following an Ostwald ripening process, resulting in the protein-capped CdTe QDs with tailored size and excellent crystallinity. The protein cap confinement leads to the uniform size and good degree of dispersion without any aggregation. The CdTe QDs obtained by the extracellular growth approach can be easily isolated from the yeast cells by centrifugation, showing an obvious advantage over processes for the intracellular biosynthesis of CdS [26] and CdSe [27] QDs that require complicated procedures-including cell wash, disruption, and fragment removal-to obtain the isolated QDs. It has been reported that QDs without surface conjugation cannot be transported into bacteria owing to the lack of an endocytosis pathway [34], whereas in our system the extracellularly proteincapped CdTe QDs can be taken up by the yeast cells and dispersed throughout the cytoplasm and nucleus domains (as shown by in situ bio-imaging under LSCM). In this case, we assume that the protein-capped QDs first become adhered to the cell membrane via electrostatic interaction (step I in Fig. 7(b)), then gradually become embedded by deforming the membrane and endocytose into the cell (step II), are then released from the endosome into the cytoplasm by disruption of the endosomal membrane (step III) and finally enter the nucleus via a nuclear translocation (step IV) [35]. It is worth noting that the quantum yield of the as-biosynthesized greenemitting CdTe QDs is $\sim 33 \%$ at a reaction temperature of $35^{\circ} \mathrm{C}$, which is higher than that observed for high quality $\mathrm{CdTe}$ nanocrystals obtained under hydrothermal conditions at a temperature of $180{ }^{\circ} \mathrm{C}$ [17], indicating that the biosynthesized CdTe QDs are a good candidate for bio-imaging.

\section{Conclusions}

A novel, efficient, and simple biosynthesis approach to prepare highly fluorescent protein-capped $\mathrm{CdTe}$ quantum dots has been developed by incubating yeast cells with cheap inorganic $\mathrm{Cd}$ and Te precursors. The extracellularly biogrown CdTe QDs show relatively uniform and tunable size $(2.0-3.6 \mathrm{~nm})$, and good crystallinity with a cubic zinc blende structure. The biosynthesized CdTe QDs show intense fluorescence, and varying the particle size allows the emission to be tuned over the range from 490 to $560 \mathrm{~nm}$. The proteincapped CdTe QDs show excellent biocompatibility and are well dispersed in the cells, and in situ bioimaging of the yeast cells is easily achieved. We propose that an extracellular growth pathway is responsible for the formation of the protein-capped CdTe QDs and an endocytosis pathway is responsible for the in situ bio-imaging results. In comparison with other synthesis routes, our strategy allows the one-step preparation of protein-capped CdTe QDs on a large scale (gram quantities) in aqueous solutions at relatively low temperatures $\left(25-35^{\circ} \mathrm{C}\right)$. Moreover, the proteins capped on the QDs offer not only high biocompatibility of the QDs but also functional groups for further chemical modifications. As a consequence, these protein-capped CdTe QDs are expected to be extremely useful for bio-imaging and bio-labeling applications.

\section{Acknowledgements}

This work was supported by Discovery Grants from the Australian Research Council (No. DP0879769). 
Electronic Supplementary Material: Additional TEM HPLC, and LSCM data are available in the online version of this article at http://dx.doi.org/10.1007/ s12274-010-0008-6 and accessible free of charge.

Open Access: This article is distributed under the terms of the Creative Commons Attribution Noncommercial License which permits any noncommercial use, distribution, and reproduction in any medium, provided the original author(s) and source are credited.

\section{References}

[1] Alivisatos, A. P. Perspectives on the physical chemistry of semiconductor nanocrystals. J. Phys. Chem. 1996, 100, 13226-13239.

[2] Alivisatos, A. P. Semiconductor clusters, nanocrystals, and quantum dots. Science 1996, 271, 933-937.

[3] Murray, C. B.; Norris, D. J.; Bawendi, M. G. Synthesis and characterization of nearly monodisperse $\mathrm{CdE}(\mathrm{E}=\mathrm{S}, \mathrm{Se}, \mathrm{Te})$ semiconductor nanocrystallites. J. Am. Chem. Soc. 1993, 115, 8706-8715.

[4] Peng, X. G.; Manna, L.; Yang, W. D.; Wickham, J.; Scher, E.; Kadavanich, A.; Alivisatos, A. P. Shape control of CdSe nanocrystals. Nature 2000, 404, 59-61.

[5] Zheng, Y. G.; Yang, Z. C.; Ying, J. Y. Aqueous synthesis of glutathione-capped $\mathrm{ZnSe}$ and $\mathrm{Zn}_{1-x} \mathrm{Cd}_{x} \mathrm{Se}$ alloyed quantum dots. Adv. Mater. 2007, 19, 1475-1479.

[6] Huynh, W. U.; Dittmer, J. J.; Alivisatos, A. P. Hybrid nanorod-polymer solar cells. Science 2002, 295, 2425-2427.

[7] Gaponik, N. P.; Talapin, D. V.; Rogach, A. L. A lightemitting device based on a CdTe nanocrystal/polyaniline composite. Phys. Chem. Chem. Phys. 1999, 1, 1787-1789.

[8] Bruchez, M.; Moronne, M.; Gin, P.; Weiss, S.; Alivisatos, A. P. Semiconductor nanocrystals as fluorescent biological labels. Science 1998, 281, 2013-2016.

[9] Chan, W. C. W.; Nie, S. M. Quantum dot bioconjugates for ultrasensitive nonisotopic detection. Science 1998, 281, 2016-2018.

[10] Mamedova, N. N.; Kotov, N. A.; Rogach, A. L.; Studer, J. Albumin-CdTe nanoparticle bioconjugates: Preparation, structure, and interunit energy transfer with antenna effect. Nano Lett. 2001, 1, 281-286.

[11] Chen, W.; Grouquist, D.; Roark, J. Voltage tunable electroluminescence of CdTe nanoparticle light-emitting diodes. J. Nanosci. Nanotech. 2002, 2, 47-53.

[12] Zhang, H.; Cui, Z. C.; Wang, Y.; Zhang, K.; Ji, X. L.; Lu, C. L.; Yang, B.; Gao, M. Y. From water-soluble CdTe nanocrystals to fluorescent nanocrystal-polymer transparent composites using polymerizable surfactants. Adv. Mater. 2003, 15, 777-780.

[13] Ma, J.; Chen, J. Y.; Guo, J.; Wang, C. C.; Yang, W. L.; Xu, L.; Wang, P. N. Photostability of thiol-capped CdTe quantum dots in living cells: The effect of photo-oxidation. Nanotechnology 2006, 17, 2083-2089.

[14] Peng, Z. A.; Peng, X. G. Formation of high-quality CdTe, $\mathrm{CdSe}$, and $\mathrm{CdS}$ nanocrystals using $\mathrm{CdO}$ as precursor. J. Am. Chem. Soc. 2001, 123, 183-184.

[15] Talapin, D. V.; Haubold, S.; Rogach, A. L.; Kornowski, A.; Haase, M.; Weller, H. A novel organometallic synthesis of highly luminescent CdTe nanocrystals. J. Phys. Chem. B 2001, 105, 2260-2263.

[16] Rogach, A. L.; Katsikas, L.; Kornowski, A.; Su, D. S.; Eychmuller, A.; Weller, H. Synthesis and characterization of thiol-stabilized CdTe nanocrystals. Ber. Bunsenges. Phys. Chem. 1996, 100, 1772-1778.

[17] Zhang, H.; Wang, L. P.; Xiong, H. M.; Hu, L. H.; Yang, B.; Li, W. Hydrothermal synthesis for high-quality CdTe nanocrystals. Adv. Mater. 2003, 15, 1712-1715.

[18] Bao, H. F.; Wang, E. K.; Dong, S. J. One-pot synthesis of CdTe nanocrystals and shape control of luminescent CdTe-cystine nanocomposites. Small 2006, 2, 476-480.

[19] Bao, H. F.; Cui, X. Q.; Li, C. M.; Zang, J. F. Shapecontrolled assembly of luminescent dumbbell-like CdTecystine nanocomposites. Nanotechnology 2007, 18, 455701.

[20] Dahl, J. A.; Maddux, B. L. S.; Hutchison, J. E. Toward greener nanosynthesis. Chem. Rev. 2007, 107, 2228-2269.

[21] Ahmad, A.; Mukherjee, P.; Mandal, D.; Senapati, S.; Khan, M. I.; Kumar, R.; Sastry, M. Enzyme mediated extracellular synthesis of CdS nanoparticles by the fungus, Fusarium oxysporum. J. Am. Chem. Soc. 2002, 124, 12108-12109.

[22] Kowshik, M.; Deshmukh, N.; Vogel, W.; Urban, J.; Kulkarni, S. K.; Paknikar, K. M. Microbial synthesis of semiconductor $\mathrm{CdS}$ nanoparticles, their characterization, and their use in the fabrication of an ideal diode. Biotechnol. Bioeng. 2002, 78, 583-588.

[23] Kowshik, M.; Vogel, W.; Urban, J.; Kulkarni, S. K.; Paknikar, K. M. Microbial synthesis of semiconductor PbS nanocrystallites. Adv. Mater. 2002, 14, 815-818.

[24] Bai, H. J.; Zhang, Z. M.; Gong, J. Biological synthesis of semiconductor zinc sulfide nanoparticles by immobilized Rhodobacter sphaeroides. Biotechnol. Lett. 2006, 28, 1135-1139.

[25] Sweeney, R. Y.; Mao, C. B.; Gao, X. X.; Burt, J. L.; Belcher, A. M.; Georgiou, G.; Iverson, B. L. Bacterial biosynthesis of cadmium sulfide nanocrystals. Chem. Biol. 2004, 11, 1553-1559. 
[26] Kang, S. H.; Bozhilov, K. N.; Myung, N. V.; Mulchandani, A.; Chen, W. Microbial synthesis of CdS nanocrystals in genetically engineered E. coli. Angew. Chem. Int. Ed. 2008, 47, 5186-5189.

[27] Cui, R.; Liu, H. H.; Xie, H. Y.; Zhang, Z. L.; Yang, Y. R.; Pang, D. W.; Xie, Z. X.; Chen, B. B.; Hu, B.; Shen, P. Living yeast cells as a controllable biosynthesizer for fluorescent quantum dots. Adv. Funct. Mater. 2009, 19, 2359-2364.

[28] Bao, H. F.; Lu, Z. S.; Cui, X. Q.; Qao, Y.; Guo, J.; Anderson, J. M.; Li, C. M. Extracellular microbial synthesis of biocompatible CdTe quantum dots. Acta Biomater., in press, DOI: 10.1016/j.actbio.2010.03.030.

[29] Gao, M. Y.; Kirstein, S.; Mohwald, H.; Rögach, A. L.; Kornowski, A.; Eychmüller, A.; Weller, H. Strongly photoluminescent CdTe nanocrystals by proper surface modification. J. Phys. Chem. B 1998, 102, 8360-8363.

[30] Yu, W. W.; Qu, L. H.; Guo, W. Z.; Peng, X. G. Experimental determination of the extinction coefficient of CdTe, CdSe, and CdS nanocrystals. Chem. Mater. 2003, 15, 2854-2860.
[31] Gaponik, N.; Talapin, D. V.; Rogach, A. L.; Hoppe, K.; Shevchenko, E. V.; Kornowski, A.; Eychmuller, A.; Weller, H. Thiol-capping of CdTe nanocrystals: An alternative to organometallic synthetic routes. J. Phys. Chem. B 2002, 106, 7177-7185.

[32] Vido, K.; Spector, D.; Lagniel, G.; Lopez, S.; Toledano, M. B.; Labarre, J. A proteome analysis of the cadmium response in Saccharomyces cerevisiae. J. Biol. Chem. 2001, 276, 8469-8474.

[33] Massardo, D. R.; Pontieri, P.; Maddaluno, L.; De Stefano, M.; Alifano, P.; Del Giudice, L. Effects of tellurite on growth of Saccharomyces cerevisiae. BioMetals 2009, 22, 1089-1094.

[34] Kloepfer, J. A.; Mielke, R. E.; Nadeau, J. L. Uptake of $\mathrm{CdSe}$ and $\mathrm{CdSe} / \mathrm{ZnS}$ quantum dots into bacteria via purinedependent mechanisms. Appl. Environ. Microb. 2005, 71, 2548-2557.

[35] Xu, Z. P.; Zeng, Q. H.; Lu, G. Q.; Yu, A. B. Inorganic nanoparticles as carriers for efficient cellular delivery. Chem. Eng. Sci. 2006, 61, 1027-1040. 